\title{
Creating Cultural and Commercial Value in Late Nineteenth-Century New York Art Catalogues
}

\author{
Leanne Zalewski
}

Dealers, collectors, critics and auctioneers in late nineteenth-century New York created cultural and commercial value through collections, sales and auction catalogues. Scholars have examined various aspects of the New York art market, such as blockbuster auctions, class identity and the effect of business practices on collecting, but the catalogues themselves remain largely unexamined. ${ }^{1}$ Nicholas Green, who focused on the Paris art market, noted that sale catalogues provided publicity for French auction sales from the mid-1850s

1 I wish to thank Jan Dirk Baetens, Dries Lyna, Andrea Lepage and Lindsay Twa for their valuable input on earlier drafts of this chapter.

See: John Ott, "How New York Stole the Art Market: Blockbuster Auctions and Bourgeois Identity in Gilded Age America," Winterthur Portfolio 42, no. 2-3 (2008): 133-58; Sven Beckert, "Institution-Building and Class Formation: How the Nineteenth-Century Bourgeoisie Organized," in The American Bourgeoisie: Distinction and Identity in the Nineteenth Century, eds. Sven Beckert and Julia Rosenbaum (New York: Palgrave Macmillan, 2011), 103-17; Albert Boime, "America's Purchasing Power and the Evolution of European Art in the Late Nineteenth Century," in Saloni, gallerie, musei e loro influenza sullo sviluppo dell'arte dei secoli xix e xx, ed. Francis Haskell (Bologna: CLUEB, 1979), 123-39; Madeleine Fidell-Beaufort and Jeanne K. Welcher, "Some Views of Art Buying in New York in the 1870 s and 188os," Oxford Art Journal 5, no. 1 (September 1982): 48-55; Madeleine Fidell-Beaufort, "A Measure of Taste: Samuel P. Avery's Art Auctions, 1864-1880," Gazette des beaux-arts 100 (1982): 87-9; Id., "Art Collecting in the United States after the Civil War: Civic Pride, Competition, and Personal Gains," in Artwork through the Market: The Past and the Present, ed. Ján Bakos (Bratislava: VEDA, 2004), 125-36; Id., "The American Art Trade and French Painting at the End of the Nineteenth Century," Van Gogh Museum Journal 6 (2000): 101-7; Malcolm Goldstein, Landscape with Figures: A History of Art Dealing in the United States (New York: Oxford University Press, 2000). For other related studies, see: DeCourcey E. McIntosh, Gabriel P. Weisberg, and Alison McQueen, eds., Collecting in the Gilded Age: Art Patronage in Pittsburgh, 1890-1910 (Pittsburgh: Frick Art \& Historical Center, Hanover - London: University Press of New England, 1997); Linda Henefield Skalet, "The Market for American Painting in New York: 1870-1915" (PhD diss., Johns Hopkins University, 1980); John Ott, Manufacturing the Modern Patron in Victorian California (Burlington: Ashgate, 2014); Thomas M. Bayer and John R. Page, The Development of the Art Market in England: Money as Muse, 1730-19oo (London: Pickering \& Chatto, 2011); Pamela Fletcher and Anne Helmreich, eds., The Rise of the Modern Art Market in London: 1850-1939 (Manchester - New York: Manchester University Press, 2011).

(C) LEANNE ZALEWSKI, 2019 | DOI:10.1163/9789004291997_005

This is an open access chapter distributed under the terms of the prevailing CC-BY-NC License at the time of publication. 
onwards. ${ }^{2}$ American catalogues became prevalent a few decades later and served as more than publicity for sales and exhibitions. What information did American catalogues communicate about artists, schools and nationality? Increased cultural mobility, largely among the wealthy and the dealers who worked with them, transformed the cultural landscape in New York for its inhabitants. ${ }^{3}$ This internationalism enhanced the cultural merit and commercial value of the works sold or exhibited by some of the leading collectors. Overall these catalogues reveal that American collectors sought cultural sophistication through internationalism, particularly foreign institutional recognition. ${ }^{4}$ The catalogues reflected what sociologist Pierre Bourdieu explained as a "material type of capital" transformed into cultural and social capital. ${ }^{5}$ But first, Americans needed material capital.

Prior to the American Civil War (1861-5) the art market in New York focused primarily on American art, but after the war a buying frenzy took place through the early 189os. The internationalisation of New York's art market resulted from economic shifts and greater cultural mobility at the end of the Civil War. Industrialists and financiers rose to prominence and accumulated wealth never before obtained in the United States. Affluence increased travel abroad, where collectors met artists, visited galleries and museums and purchased artworks. Greater contact between the United States and Europe facilitated the purchase of contemporary foreign artworks. As wealth increased, the number of collectors increased. I call this period the "Postbellum Picture Boom," a time of rapidly increased picture buying, primarily French art supplemented by art from various other European national "schools". ${ }^{6}$ Strengthening ties to France

2 Nicholas Green, "Dealing in Temperaments: Economic Transformation of the Artistic Field in France during the Second Half of the Nineteenth Century," in Critical Readings in Impressionism and Post-Impressionism: An Anthology, ed. Mary Tompkins Lewis (Berkeley: University of California Press, 2007), 36. For a detailed study of dealers, critics, artists and auctions in Paris, see: Harrison C. and Cynthia A. White, Canvases and Careers: Institutional Change in the French Painting World (Chicago: University of Chicago Press, 1993).

3 See: Stephen Greenblatt et al., Cultural Mobility: A Manifesto (Cambridge: Cambridge University Press, 2010), 250-3. For a summary of Greenblatt's manifesto, see also: http:// www.fas.harvard.edu/ cardenio/mobility.html.

4 Lloyd Kramer, Nationalism in Europe \& America: Politics, Cultures, and Identities since 1775 (Chapel Hill: University of North Carolina Press, 2011), 4.

5 Pierre Bourdieu, "The Forms of Capital (1986)," in Education: Culture, Economy and Society, ed. A.H. Halsey et al. (Oxford: Oxford University Press, 1997), 46.

6 My forthcoming book, The Postbellum Picture Boom: European Art, American Aspirations, 1867-1893, further explains the "Postbellum Picture Boom" and significance of international expositions. 
by promoting the taste for contemporary French art in the United States, the capital of culture fostered an aesthetic sophistication.

Collectors bought primarily through dealers acting as intermediaries who facilitated cultural transfers. ${ }^{7}$ They included New York-based art dealers Samuel P. Avery (1822-1904), Michael Knoedler (1823-78) and American-born Paris-based dealer George A. Lucas (1824-1909), all of whom in turn dealt with leading French dealers, such as Goupil \& Cie and Galerie Georges Petit in Paris. ${ }^{8}$ Lucas, Avery, Knoedler and Goupil supplied much of the art to American collectors. Lucas, who remained in Paris, and Avery, who travelled abroad annually, made the transfer of objects possible by accompanying patrons to artists' studios and exhibitions overseas and by serving as agents abroad. The dealers and collectors sent many European artworks to the United States. Collectors also attended auctions and would occasionally make some of their purchases directly from foreign dealers.

By the 1870 s the New York art market had developed transatlantic relationships and catalogue entries expanded to reflect training, provenance and awards garnered by foreign artists. American schools lacked the complex system of awards in European academies. Bourdieu identified these institutional award systems as a means of conveying cultural capital. ${ }^{9}$ Catalogues from the 1870 and 1880 s included far more information about the artists than had catalogues prior to the "Postbellum Picture Boom." Later catalogue entries provided lists of awards that implied validation and success and communicated to American readers the cultural and financial value of the works, the internationalisation of the market and collectors' knowledge and sophistication, in other words, cultural and social capital. Expanded catalogue entries thus enhanced the meanings of the artworks and informed readers about art institutions abroad.

7 Greenblatt termed these intermediaries 'mobilizers.' See: Greenblatt, Cultural Mobility, 251.

8 See: Samuel P. Avery, The Diaries 1871-1882 of Samuel P. Avery, eds. Madeleine Fidell-Beaufort, Herbert L. Kleinfield, and Jeanne K. Welcher (New York: Arno Press, 1979); George A. Lucas, Diary of George A. Lucas: An American Art Agent in Paris, 1857-19o9, ed. Lilian M.C. Randall, 2 vols. (Princeton: Princeton University Press, 1979). See also: Agnès Penot, La maison Goupil. Galerie d'art internationale au XIX ${ }^{e}$ siècle (Paris: Mare \& Martin, 2016). The M. Knoedler \& Co. records, 1848-1971, and Goupil \& Cie/Boussod, Valadon \& Cie. records, are housed in Special Collections, Getty Research Institute, Los Angeles, CA. Goupil et Cie stock books are available in a searchable online database at: http://www.getty.edu/research/tools/digital_collections/goupil_cie/books.html.

9 Bourdieu, "The Forms of Capital," 50-1. 


\section{National Schools of Art in American Collection Catalogues}

Prior to the influx of contemporary European art after the Civil War, American art critics had already been thinking about national schools, particularly what constituted an American school. "School" referred to shared characteristics among a nation's artistic output. A reviewer for the Bulletin of the American Art-Union addressed this issue: 'Let us examine [...] into the desirability of this quality which we have called Nationality. We have defined it as the attainment to a School, or a distinctive manner of thinking upon, or regarding the subjects of art, corresponding to some trait of the national mind. ${ }^{10}$ However, little analysis followed on what traits distinguished the 'national mind[s]' of different schools. Clearly defined traits required expertise and connoisseurship, when such expertise, and a critical distance, had not yet developed in the United States.

Lacking in contemporary artists' catalogue entries were distinctive traits such as those found in an 1853 didactic handbook to the Thomas Jefferson Bryan catalogue of old master paintings. The Bryan catalogue was possibly the first in New York published simply to document an important collection and to educate readers. ${ }^{11}$ In the 1850 s a general lack of knowledge necessitated an educational tone in part to help others identify authentic from inauthentic works, but it failed in Bryan's case. Although his collection was later found to contain mainly inauthentic or misattributed paintings, Bryan's catalogue attempted to teach readers about these unfamiliar works. For example, an entry for the Dutch seventeenth-century artist Gerrit Dou describes his technical strengths: 'His aim was to unite the powerful tones and strongly opposed light and shade of REMBRANDT, to the most delicate handling and highest finish. [...] He is unequalled in his style. ${ }^{12}$ However, few American critics defined shared characteristics of the various national schools for catalogues of living artists' works.

Critics made only vague and infrequent attempts to articulate distinguishable traits for national schools. For example, one writer associated French art with strong sensuality, power and energy; German art with rationalism;

\footnotetext{
10 Anon., "Development of Nationality in American Art," Bulletin of the American Art-Union, no. 9 (1851): 137 .

11 Thomas Jefferson Bryan, Companion to the Bryan Gallery of Christian Art (New York: Baker, Godwin \& Co., 1853). I mistakenly identified William Henry Vanderbilt's catalogues as the first in an earlier article: Leanne Zalewski, "Art for the Public: William Henry Vanderbilt's Cultural Legacy," Nineteenth-Century Art Worldwide 11, no. 2 (Summer 2012), http://www.19thc-artworldwide.org/summerı/leanne-zalewski-william-henry-vanderbilts-cultural-legacy (accessed 28 June 2015). 
and English with a 'reverence for truth and authority.'13 Although no unified American school seemed evident in the 1867 Paris universal exhibition, an American critic offered the terms 'vastness and loneliness' as an attempt to differentiate American from British landscape painting. ${ }^{14}$ Such commentary was published in journals and newspapers rather than in collection catalogues. Catalogue entries for private collections contained factual content rather than assessments. Any opinions expressed were in the form of an artist's letter written to the collector.

National schools were separated but not defined in the first major New York sale including contemporary European art. John Wolfe, a businessman, sold his collection at auction in 1863 . The only catalogue extant for that sale was printed afterwards, with a simple list of the artists' names, subject of the works, purchasers' names and prices paid. The artists were grouped under headings including 'American School,' 'English School,' 'French School,' 'German School' and 'Belgian and Dutch School.' ${ }^{15}$ No descriptions distinguished these national schools. Similarly vague was an 1866 auction catalogue featuring mainly American art that only listed the artists' names, cities, and artwork titles, such as 'E. Vedder, New York.'16 American artists had no honours or awards listed after their names. In contrast, the few foreign works included additional information, naming awards, for example, 'Richaud, of Paris; medal, 1848. ${ }^{17}$ The foreign works were not separated by headings, as in the Wolfe catalogue, and offered little information. Later catalogues gave more information, but none identified traits of national schools.

Collections formed during the "Postbellum Picture Boom" included artworks from various national schools, as Wolfe's 1863 collection. Having at least a few examples of leading artists from other European nations sufficed to create a heterogeneous collection. ${ }^{18}$ Foremost among the artists American collectors

13 Anon., "Development of Nationality in American Art," 138.

14 Carol Troyen, "Innocents Abroad: American Painters at the 1867 Exposition Universelle, Paris," American Art Journal 16, no. 4 (1984): 13; M.D. Conway, "The Great Show at Paris," Harper's New Monthly 35, no. 206 (1867): 248.

15 Catalogue of a Private Collection of Original Modern Oil Paintings and Water Color Drawings Belonging to J. Wolfe [...] To Be Sold by Auction [...] December, 1863 (New York: Henry H. Leeds \& Co, 1863).

16 Catalogue of a Remarkably Fine Collection of Oil Paintings by the Best American Artists, Also, A Number of Choice Foreign Works [...] Consigned to Mr. S.P. Avery (New York: Henry H. Leeds \& Miner, 1866), 1.

17 Ibid.

18 Artist and author, Earl Shinn, documented the collections in the deluxe, illustrated three-volume set, Art Treasures of America. Edward Strahan [Earl Shinn], Art Treasures of America, 3 vols. (Philadelphia: George Barrie, 1879-82). 
patronised were French academic artists who specialised in genre, historical genre, animal and landscape subjects, Orientalist and military subjects. ${ }^{19}$ An image of Avery atop crates of artworks shipped overseas exemplifies the transfer of fine and decorative artworks from Europe to the United States (Fig. 3.1) and the variety of schools represented. Cartons of Chinese, Japanese and Sèvres porcelains complement the stacks of paintings. In the caricature Avery carries a banner inscribed with the well-known names of artists, listed top to bottom: León Escosura (Spanish), Jehan-Georges Vibert (French), Adolphe Schreyer (German), Alexandre Cabanel (French), Raimundo Madrazo (Spanish), George Boughton (Anglo-American) and Édouard Detaille (French). Three of the seven are French artists. Although less numerous in collections than French works, other popular artists included genre painters Ludwig Knaus (Prussian), Mihaly Munkácsy (Hungarian), Mariano Fortuny (Spanish) and Alfred Stevens (Belgian), as well as sheep painter Eugène Verboeckhoven (Belgian), animal painter Sir Edwin Landseer (English) and Dutch landscapists from the Hague school, such as Hendrik Willem Mesdag. ${ }^{20}$ Every important collection had representative works by most or all of these artists. The most select collections included rarer works by the "Hungarian Meissonier," August von Pettenkofen, and the much-admired Belgian history painter Henri Leys. ${ }^{21}$ Some collections also included a modest number of American pictures.

Catalogues reflect the diverse artists' nationalities. Sales and collection catalogues listed artists by name, location, city rather than country (i.e., Paris, Düsseldorf, Munich, The Hague and New York rather than French, German, etc.). The city indicated which fine arts school the artist had attended. Entries also often included biographical notes, which listed artists alphabetically. ${ }^{22}$ Longer entries accompanied the better-known artists' works. Some included

19 Much work has been done on some academic artists' reception in the United States. See for example: Gérôme and Goupil: Art and Enterprise (Paris: Réunion des musées nationaux, New York: Dahesh Museum of Art, 200o); Robert Isaacson, "Collecting Bouguereau in England and America," in William Bouguereau, 1825-1905 (Montreal: Montreal Museum of Art, 1984), 104-13; Eric M. Zafran, "William Bouguereau in America: A Roller-Coaster Reputation," in In the Studios of Paris: William Bouguereau and his American Students, ed. James F. Peck (Tulsa: Philbrook Museum of Art, New Haven: Yale University Press, 2006), 17-44; Laura L. Meixner, French Realist Painting and the Critique of American Society, 18651900 (New York: Cambridge University Press, 1995).

20 See: Renske Cohen Tervaert, "Lart pour l'argent," (MA thesis, University of Amsterdam, 2008), which deals with Mesdag.

21 For more on Leys, see the forthcoming book by Jan Dirk Baetens: Henri Leys and the Resurrection of the Past (Leuven: Leuven University Press).

22 Catalogue of the A.T. Stewart Collection of Paintings, Sculptures, and Other Objects of Art (New York: American Art Association, 1887). 


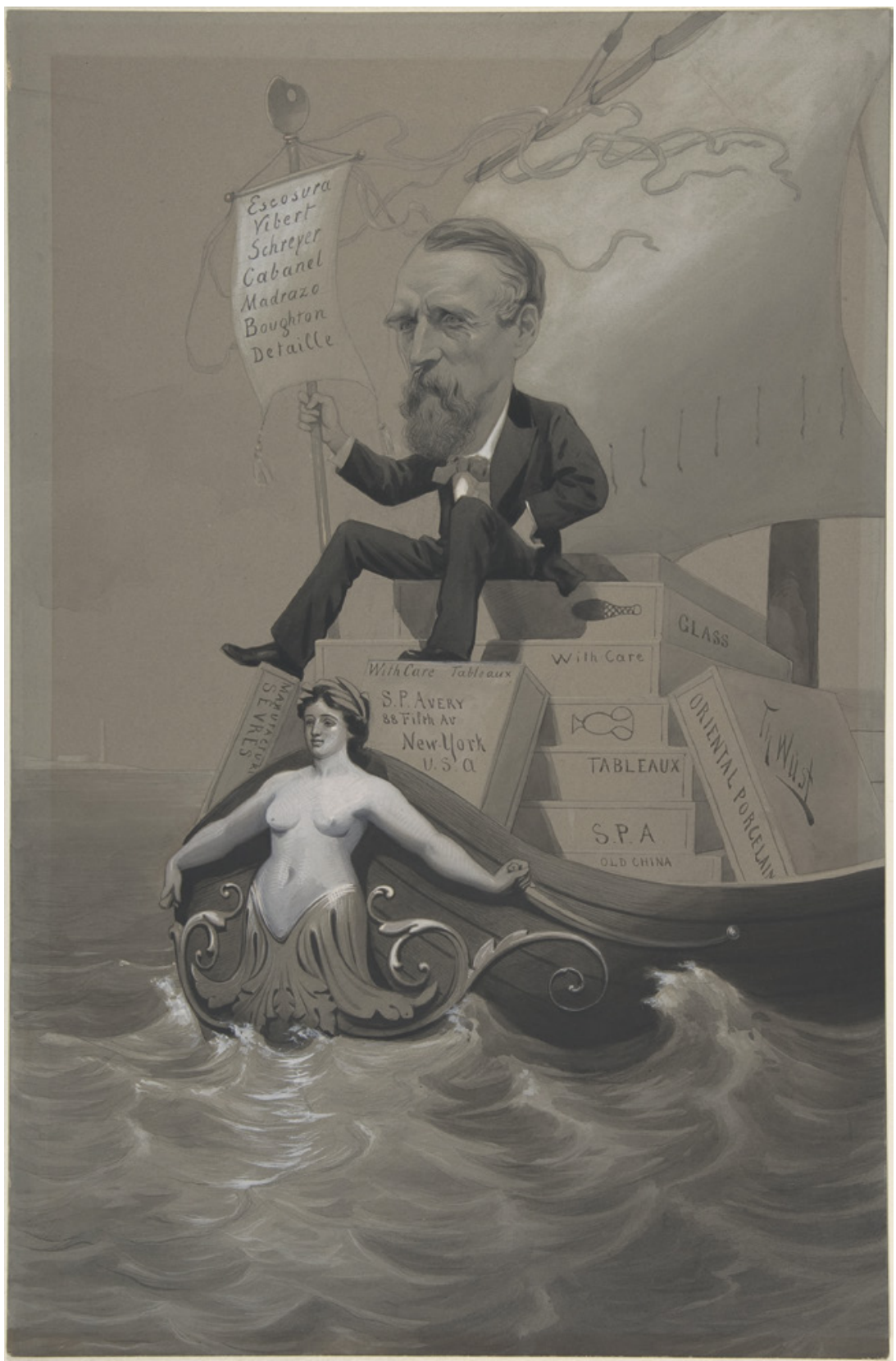

FIG URE 3.1 Theodore Wust, Samuel P. Avery Transporting his Treasures Across the Sea, c. $1875^{-80}$. Graphite, ink and gouache on grey paper, $40.9 \times 26.7 \mathrm{~cm}$. New York, The Metropolitan Museum of Art. Gift of Emma Avery Welcher and Amy Ogden Welcher and Alice Welcher Erickson, 1967 (C) THE METROPOLITAN MUSEUM OF ART 
lengthy letters from the artist to the collector describing the work. As with today's auction catalogues, these longer entries signified the importance of the painting.

American catalogues tended to follow French models, notably the Luxembourg Museum catalogue format rather than the Paris Salon or wellknown French auction catalogues, such as that of the 1872 Isaac and Émile Pereire collection. ${ }^{23}$ The Pereire catalogue, representative of high-profile collections, included only the artists' names, titles of the artworks, short descriptions, dates and dimensions, as below:

\section{GÉRÔME \\ 20-Pifferari à Rome.}

Deux pifferari sont arrêtés devant une madone, dans une rue de Rome et jouent de leurs instruments; un petit garçon fait aussi sa partie dans le concert.

Daté 1859 .

Bois Haut., $38 \mathrm{~cm}$; larg., $29 \mathrm{~cm}^{24}$

Such a famous collection needed no embellishments or list of honours. The artists were already established in France. The French sale catalogue differed from the Paris Salon catalogue of the same year. Henner's two entries exemplify the typical entry:

HENNER (JEAN-JACQUES), né à Bernwiller (Alsace), élève de Drölling et de Picot.-Hors concours.

Place Pigalle, 11.

1016-Le Christ mort.

1017-Portrait de Mme Karakéhia. ${ }^{25}$

The Salon entry gave the artist's name, birthplace and current address, teacher, artwork title and indicated whether the artist was no longer required to submit work to the jury for admission (hors concours). Longer entries in the Luxembourg Museum catalogue were more informative. American visitors would have been

23 Résumé du catalogue des tableaux anciens et modernes des diverses écoles, dont la vente aura lieu [...] les 6, 7, 8, et 9 mars 1872 [...]: galerie de MM. Pereire (Paris: François Petit, 1872).

24 Id., 11.

25 Explication des ouvrages de peinture, sculpture, architecture, gravure et lithographie des artistes vivants, exposés au Palais des Champs-Élysées le 1er mai 1876 (Paris: Imprimerie nationale, 1876), 126. 
familiar with the museum. Its catalogues listed the artists' names, their native towns, teachers, awards and the Salons at which the paintings were exhibited. ${ }^{26}$ An entry in the 1872 Luxembourg Museum catalogue reads:

BAUDRY (PAUL-JACQUES-AIMÉ), né à Napoléon-Vendée (Vendée), élève de Sartoris et de Drolling; grand prix de Rome (Histoire) en 1850, chevalier de la Légion d'Honneur en 1861, officier en 1869; membre de l'Institut en 1870.

12. La Fortune et le jeune Enfant.

La Fortune passa, l'éveille doucement,

Lui disant: mon mignon, je vous sauve la vie;

Soyez une autre fois plus sage, je vous prie.

(LA FONTAINE.)

H. 1,92.—L. 1, 46.—Fig. gr. Nat. [Figure grandeur naturelle]

$(\text { Salon de 1857. })^{27}$

When available, these short passages from literary sources, such as La Fontaine for Baudry's entry, indicated importance in its longer entry. Most other artists' entries included birthplace, teacher(s), awards, artwork title, dimensions and Salon exhibition year.

Four representative catalogues of leading New York collections drew from these models: the August Belmont special fundraising exhibition catalogue (1877), the Alexander T. Stewart auction sale catalogue (1887), the William Henry Vanderbilt collection catalogue (1886) and the Catharine Lorillard Wolfe Collection published by the Metropolitan Museum of Art (1887)..28 The 1886 William Henry Vanderbilt collection catalogue was later republished verbatim

26 See for example: Notice des peintures, sculptures et dessins de l'école moderne exposés dans les galeries du Musée national du Luxembourg (Paris: Charles de Mourgues frères, 1875).

27 Id., 3-4.

28 Public Exhibition of the Belmont Collection for the Benefit of the Family of the Late Artist, Mr. J. Beaufain Irving (New York, 1877); Catalogue of the A.T. Stewart Collection; Catalogue of the W.H. Vanderbilt Collection of Paintings (New York: De Vinne Press, 1886); Metropolitan Museum of Art. Part I. The Catharine Lorillard Wolfe Collection (New York: Metropolitan Museum of Art, 1887), 1-25. The catalogue lists 142 works on view. [Samuel P. Avery], "Catharine Lorillard Wolfe Collection and Other Modern Paintings in the Western Galleries, Stairways, and Grand Hall," Metropolitan Museum of Art Handbook No. 1 (New York: Metropolitan Museum of Art, 1894); Catalogue of the Paintings in the Metropolitan Museum of Art (New York: Metropolitan Museum of Art, 1902). 
in the Metropolitan Museum of Art Handbook when the collection was installed at the museum in $1902 .{ }^{29}$ The bulleted list below outlines the overt information included in catalogue entries and the implied information, the cultural and social capital communicated to catalogue readers.

- Overt Information

- Artist name

- Title of artwork

- Dimensions

- Artist's teacher

- Nationality (i.e., French school) or city of residence (i.e., Paris)

- Awards and honours

- Provenance

- Description of artwork/artist letter to the collector/excerpt from literary source

- Implied information transmitting social and cultural capital

- Cultural value

- Commercial value

- Artistic lineage

- Authenticity

- Internationalisation

- Collectors' knowledge

- Collectors' status

Although each of their four catalogues served a different purpose, they shared similar formats and overt and implied information. The goal was the same: to create cultural and commercial value.

Belmont, a financier and former United States minister to The Hague, and Stewart, a dry goods store magnate, assembled two of the best-known New York collections of their time, and the catalogues, ten years apart, enhanced the cultural and pecuniary value of the works. The graph below depicts the various nationalities represented in Belmont's 1877 collection and Stewart's collection at the time of its sale in 1887. Belmont acquired 114 works and Stewart owned 206 works. Each collection comprised works by nine European schools, and both collections included some American works. Although almost half of Belmont's holdings were French, he also owned modest numbers of American, Belgian, English, Dutch, German, Italian, Swiss and Norwegian works. ${ }^{30}$ Nearly

29 Catalogue of the Paintings in the Metropolitan Museum of Art (1902).

30 I included George Boughton (1833-1905) as English, although he is also considered to be American. He was born and died in England, but emigrated at a young age to Albany, New York. He moved permanently to London in 1862 . 


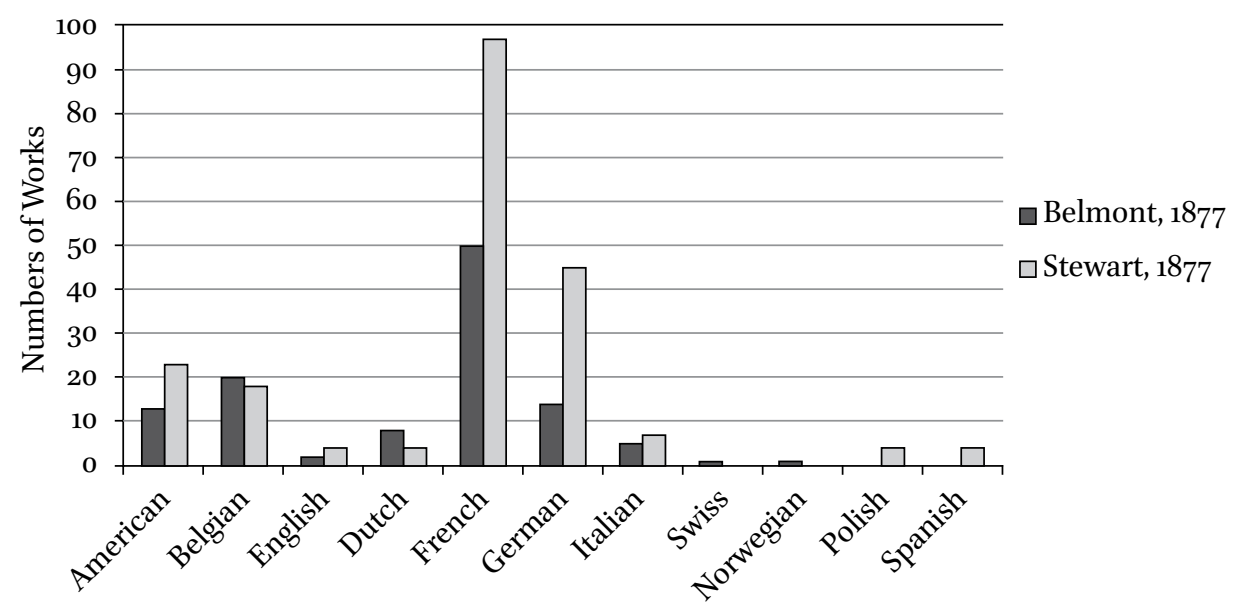

GRAPH 1 Nationalities Represented in the August Belmont (1877) and Alexander Turney Stewart (1887) Collections

half of Stewart's much larger collection was also French, followed by German, American, Belgian, Italian, Spanish, Polish, Dutch and English.

Both the Belmont and Stewart catalogues promoted commercial events. Belmont's catalogue accompanied a special exhibition to raise funds for a minor American artist's widow. No pictures were to be sold at Belmont's exhibition, held at his residence at 109 Fifth Avenue for four consecutive days. The money earned from the exhibition fees and catalogue sales helped only John Beaufain Irving's (1825-77) widow and her children. Samuel P. Avery, who helped organise Belmont's benefit exhibition, likely wrote or at least advised the preparation of the exhibition catalogue. Its preface simply indicated the fundraising purpose of the exhibition. The first entry in his catalogue reads as follows:

1. HÉBERT (E.)

Paris

Pupil of Paul Delaroche. Prize of Rome, 1839. Medals, 1851, '55, '67. Legion of Honor, 1853. Officer of the Legion of Honor, 1867. Member of the Institute of France, 1874. Commander of the Legion of Honor, 1874.

The Savoyard. ${ }^{31}$ 
Each entry listed the artist's name, city of residence, teacher, honours, and the title of the painting. The artist's artistic lineage and numerous awards sufficed to indicate his reputation.

In addition to the European paintings, a small selection of six paintings by the late Irving were included in Belmont's exhibition. Irving's entries included only the artwork's title and the name of the lender, typical for American artists. ${ }^{32}$ Irving had studied in Düsseldorf and painted in the style of Ernest Meissonier, but had not received any awards. The fact that the exhibition took place indicates that Irving had not achieved financial success from his art and had left his family in unfortunate circumstances. Instead, his widow and children relied on the proceeds from an exhibition of European art.

In contrast to Belmont's simpler exhibition catalogue, Stewart's auction catalogue, published in conjunction with the blockbuster posthumous sale of his collection, contained more overt information. ${ }^{33}$ The Stewart collection (Fig. 3.2), although not publicly exhibited as a whole during his lifetime, was well-known through descriptions. The sale catalogue from 1887 reflected its importance. The American Art Association, the auction house that handled Stewart's sale, prepared the catalogue. Stewart's catalogue began with an alphabetical listing of biographies, including lists of awards as well as artworks on display. A comparison of the entries for the same artist in Belmont's and Stewart's catalogues betrays an attempt to communicate more value for the works on view. An entry in Belmont's catalogue for the highly decorated French painter, Jean-Léon Gérôme includes only his French awards:

Pupil of Delaroche. Medals, 1847, ' 48 , ' 55 . Legion of Honor, 1855 . Member of the Institute of France, 1865. One of the Eight Grand Medals of Honor (E.U.), 1867. Officer of the Legion of Honor, 1867. Grand Medal of Honor, $1874 \cdot{ }^{34}$

Stewart's biographical catalogue entry for the same artist included far more information, a strategy aimed at enhancing the cultural and monetary value of the work and still employed today. It includes additional awards and honours bestowed on Gérôme in the intervening decade, and also his international travel. It reads:

32 Public Exhibition of the Belmont Collection, 26.

33 See: Jay E. Cantor, “A Monument of Trade: A.T. Stewart and the Rise of the Millionaire's Mansion in New York," Winterthur Portfolio 10 (1975): 165-97.

Public Exhibition of the Belmont Collection, 4. 


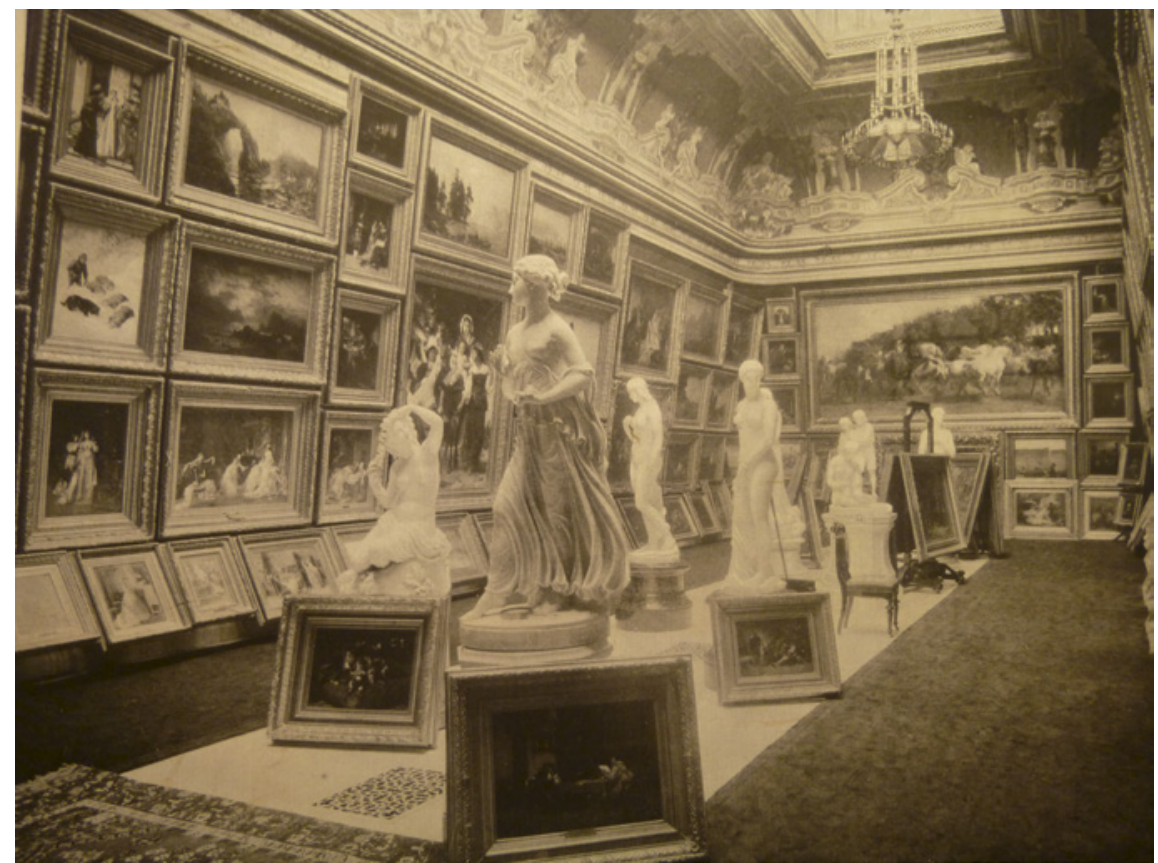

FIgure 3.2 Anon., View of Alexander T. Stewart's Private Picture-Gallery, in George Sheldon, Artistic Houses, vol. 1 (New York: D. Appleton \& Company, 1883-84), 7

Born at Vesoul, France, 1824. Went to Paris in 1841, and entered the studio of Paul Delaroche, at the same time following the course of l'École des Beaux-Arts. In 1844, he accompanied Delaroche to Italy. He made his début at the Salon of 1847. In 1853 and 1856 he travelled in Egypt and Turkey, studying closely the history and customs of those countries. Medals, Paris, 1847, 1848, 1855 (Exposition Universelle). Medal of the Institute, 1865. Medal of Honor (Exposition Universelle), 1867. Medals of Honor, 1874. Medal for Sculpture and one of the eight Grand Medals of Honor (Exposition Universelle), 1878. Legion of Honor, 1855; Officer of the same, 1867; Commander, 1878; Chevalier of the Order [sic] de l'Aigle Rouge, and Member of the Institute of France, 1878. Professor in l'École des Beaux-Arts. ${ }^{35}$

French honours were listed first, and then honours from other countries, reflecting America's broader international interests. 
Honours and memberships legitimised the work of Europeans via orders and academies lacking in the United States. Gérôme's international travels served to support his reputation as a learned ethnographer of Egyptian and Turkish subject matter. His early travel to Italy rectified his failure to secure the coveted Prix de Rome from the École des Beaux-Arts in Paris. In a sale catalogue, such as Stewart's, these long lists added cachet to the work and helped validate high prices, but they also reflected the sophisticated multicultural experiences of the artists themselves. ${ }^{36}$ Few Americans, even the wealthiest, would ever travel beyond Europe. The artist's first-hand knowledge of his subject lent credibility and added monetary value to the pictures. American collectors paid some of the highest prices for paintings by the erudite Gérôme.

Catalogue descriptions for other European artists reflected the same interest in awards and honours. History painter and portraitist Louis Gallait $(1810-87)$, well-known in nineteenth-century New York, serves as an example of the Belgian school in Stewart's catalogue:

Born at Tournai, March 10, 1810. Pupil of [Phillipe Auguste] Hennequin. Medals, 1835, 1848. Legion of Honor, 1841; Chevalier of the order of the Cross of Oak, Holland; a Member of Brussels, Antwerp, Paris, Berlin, and Munich Academies; Prussian Order of Merit; Honorary Member of the Royal Academy, London; Grand Cordon of the Order of Leopold, $1881 .{ }^{37}$

Gallait's French honours were listed first, and then honours from other countries. In contrast, the Gallait entry in the Paris Salon livret of that same year listed only his French honours:

GALLAIT (Louis), né à Tournay (Belgique), méd. 2e cl. 1835, Légion d'honneur 1841, méd. 2e cl. 1848-H.C. [hors concours]. ${ }^{38}$

The Stewart catalogue privileged the French honours by listing them first, but then embellished the entry with Gallait's international awards.

American artists' entries were padded with international contacts when such connections occurred. For example, the lengthy entry in the Stewart

36 Ott, "How New York Stole the Art Market," 152.

37 Catalogue of the A.T. Stewart Collection, 16.

38 Explication des ouvrages de peinture et dessins, sculpture, architecture et gravure des artistes vivans [...] (Paris: Paul Dupont, 1887), cxi. 
catalogue for the German-born American landscape painter Albert Bierstadt (1830-1902) includes more extraneous information than honours and emphasises his European connections, travel and training. It reads:

\section{BIERSTADT (Albert), N.A., New York}

Born in Düsseldorf, 1830. Brought to America at an early age. In 1853 he returned to Düsseldorf and entered the Academy there; afterward he also studied in Rome, Switzerland, and Germany. Elected a member of the National Academy in 1860, and later appointed Chevalier of the Legion of Honor, France. In 1867 he was sent to Europe upon a government commission, to make studies for a painting of the 'Discovery of the North River by Hendrik Hudson.' Several of his paintings are owned by the United States Government. ${ }^{39}$

Bierstadt's entry is chronological. It first explains his European heritage and training, then lists his membership to the National Academy of Design in New York. The National Academy of Design, founded in 1825, possessed a local reputation rather than an international one.

International recognition for an American artist raised his status back home. A crucial award in Bierstadt's entry is the Chevalier of the Legion of Honour bestowed upon him by Napoleon III when Bierstadt visited Paris. Bierstadt's entry also appeared in the Paris Salon livret of 1887 , the same year as the Stewart sale, although he died that year and had no pictures in the Salon. His brief livret entry, by contrast, listed only his Legion of Honour and Salon status as hors concours. ${ }^{40}$ In the Salon livrets only French honours were listed; his National Academy membership was omitted. Similarly, American artist Frederick Edwin Church's Salon livret entry listed only the second class medal that he won at the 1867 Universal Exhibition in Paris. ${ }^{41}$ French superiority seemed to require no notices of international honours and travels in the Salon livrets. American catalogues, by contrast, included as much as possible to elevate the status of the artworks and collectors, as well as their monetary value.

After the biographies in Stewart's catalogues, a separate, simpler listing of artworks followed. For example:

39 Catalogue of the A.T. Stewart Collection, 5.

$40 \quad$ Explication des ouvrages [...], cviii. Bierstadt travelled around Europe from 1867 to 1869 .

$41 \quad I d$., cix. 
No. 4

Helping the Poor

$13 \times 19$. Dated 1876

FIRMIN GIRARD,.... Paris $^{42}$

Other entries included excerpts from literature, such as Hugues Merle's Benedick and Beatrice, two characters from Shakespeare's Much Ado about Nothing. ${ }^{43}$ Some also included quotations from letters, as in Régis Gignoux's entry for The White Mountains, a landscape painting of New Hampshire's mountain range:

MR. A.T. STEWART.

DEAR SIR: I will not send any pictures to the Philadelphia Centennial, and I would be very glad to be represented at this exhibition by the two pictures you have by me, 'The White Mountains,' and the 'Niagara,' as I consider them my two most important works. [...]

Very respectfully yours,

RÉGIS GIGNOUX.

Gignoux, a French painter active in the United States, sent his letter from Paris. His French address added prestige to his entry. The letter, dated 6 March 1876, referred to the earlier date of the satellite New York Centennial Loan Exhibition to which Stewart's wife lent pictures and served as a patriotic note. ${ }^{44}$ That Gignoux considered The White Mountains one of his most important paintings may have caused potential buyers to examine it more closely and value it more highly.

The non-commercial catalogue for William Henry Vanderbilt's collection contained the same information (city, awards, honours) as Stewart's and Belmont's catalogues, but with no defining characteristics or strictly didactic information despite his educative intentions. ${ }^{45}$ Unlike the Thomas Jefferson Bryan catalogue, Vanderbilt's catalogue did not include discussions of formal elements as an attempt at connoisseurship. Vanderbilt produced four catalogues

\footnotetext{
42 Catalogue of the A.T. Stewart Collection, 44.

43 Id., 77.

44 The Philadelphia Centennial Exhibition took place from 1o May to 10 November 1876. Ultimately Gignoux was not represented at the loan exhibition. See: Kimberly Orcutt, Power and Posterity: American Art at Philadelphia's 1876 Centennial Exhibition (University Park: Penn State University Press, 2017), 41. Alexander Turney Stewart died on 10 April 1876 , shortly after receiving this letter.

45 See: Leanne Zalewski, "Art for the Public."
} 
between 1879 and 1886 for visitors to his private gallery ${ }^{46}$ In contrast to his California railroad counterpart, Leland Stanford, who published a collection catalogue in 1882 for his private art gallery, Vanderbilt did not treat the catalogue itself as a precious object. Stanford's catalogue rested inside an expensive malachite box in his reception room, attesting to his great wealth. ${ }^{47}$ There were no accounts of similar treatment of Vanderbilt's collection catalogues.

Vanderbilt's last catalogue appeared the year French author Émile Durand-Gréville visited. He called Vanderbilt's collection 'the most celebrated of all [...] by the number of its pictures, by its eclectic character, and by the assemblage of a considerable number of famous works, [which] gives the most favourable idea of the taste of the new American millionaires. 48 That a French visitor approved of this new cultural capital in the United States must have pleased collectors. Samuel P. Avery, rather than an art critic, wrote the preface to this last catalogue..$^{49}$ Neither Vanderbilt in his first three catalogues nor Belmont or Stewart in their exhibition catalogues were introduced by prefaces.

Durand-Gréville estimated that roughly two-thirds of Vanderbilt's artworks were French, followed by selections of Austrian, Belgian, Dutch, English, German, Italian and Spanish objects. ${ }^{50}$ Just a glance at the graph below shows that French paintings dominated his collection, but the smattering of artworks from other national schools served to give the collection its 'eclectic character.' The table below shows that 109 of 212 total works were French, or just over half, rather than two-thirds, a clear exaggeration by Durand-Gréville. Vanderbilt's collection included works by twelve different national schools, whereas Belmont's and Stewart's collections each contained works by nine national schools. Vanderbilt's more diverse collection included oil paintings and watercolours by Austrian, Hungarian and Scottish artists, but no Polish or Swiss artists, and only a few American artists.

Vanderbilt's collection included works by more national schools than either Belmont's or Stewart's, but his collection catalogues resembled their

46 The Private Collection of W.H. Vanderbilt, 459 Fifth Avenue, New York (New York: G.P. Putnam's Sons, 1879); Collection of W.H. Vanderbilt, 640 Fifth Avenue, New York (New York: Putnam, 1882); Collection of W.H. Vanderbilt, 640 Fifth Avenue, New York (New York: s.n., 1884); Catalogue of the W.H. Vanderbilt Collection of Paintings.

47 Ott, Manufacturing the Modern Patron in Victorian California, 70.

48 Émile Durand-Gréville, "French Pictures in America," Studio 2, no. 2 (1887): 30. His articles were published in other journals, see: Id., "Private Picture-Galleries of the United States," The Connoisseur 2, no. 3 (1888): 137-42; Id., "La peinture aux États-Unis: les galeries privées," Gazette des beaux-arts 36 (1887): 65-75.

49 Reprinted in: Catalogue of the Paintings in the Metropolitan Museum of Art (New York: Metropolitan Museum of Art, 1902), 127-8.

5o Durand-Gréville, "French Pictures in America," 30. 


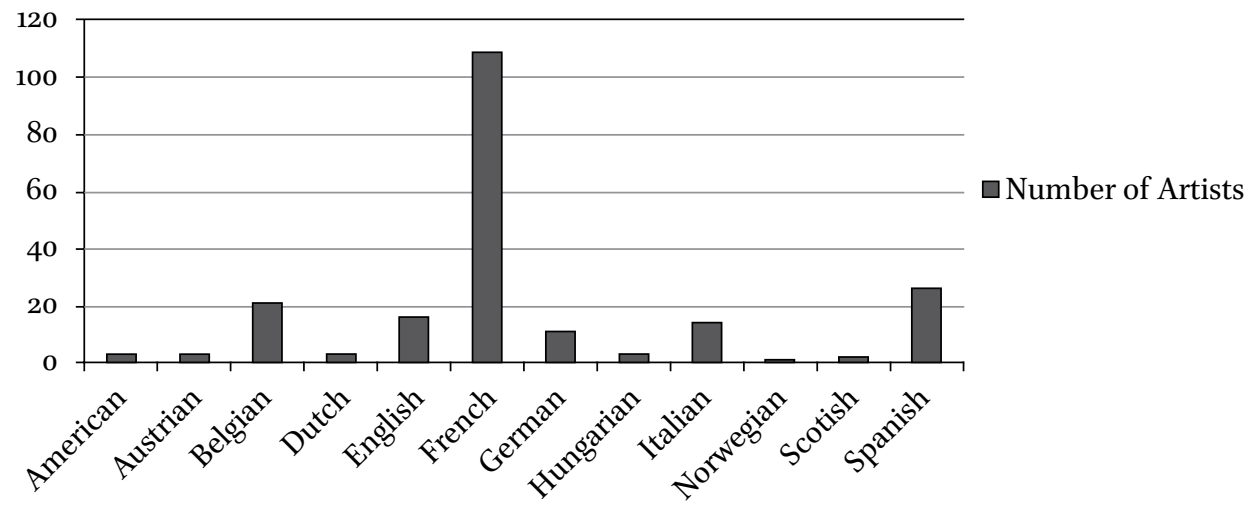

GRAPH 2 Nationalities Represented in the William Henry Vanderbilt Collection, 1886

commercial catalogues. Whether printed for a commercial endeavour or for a private venue, the information was similar. Through these catalogues and their varieties of national schools, each collector or auction house promoted cultural value through international institutional recognition.

\section{The Wolfe Collection}

One year after Vanderbilt's last collection catalogue was published, philanthropist Catharine Lorillard Wolfe donated her art collection to the Metropolitan Museum of Art, and the museum quickly published a catalogue to accompany it. Unlike Vanderbilt, Wolfe rarely opened her collection to the public while she was alive, nor did she publish a separate collection catalogue..$^{51}$ The museum's Wolfe collection handbook entries read similarly to Vanderbilt's with the artists' awards listed separately in a biographical index following the 142 entries of the artworks. In the Stewart catalogue the order was reversed: the biographical index preceded the individual entries. An example from the Wolfe handbook reads as follows:

$51 \quad$ For discussions of private art galleries in New York, see: William S. Ayres, "The Domestic Museum in Manhattan: Major Private Art Installations in New York City, 1870-1920" (PhD diss., University of Delaware, 1993); Anne McNair Bolin, "Art and Domestic Culture: The Residential Art Gallery in New York City, 1850-1870" (PhD diss., Emory University, 2000). 
Catalogue of Pictures:

48. DETAILLE, ÉDOUARD.-Skirmish between Cossacks and the Imperial Body Guard, 1814. Salon 1870. Purchased from the collection of the late Ed'd [Edward] Matthews, Esq. 1870. Canvas, $32 \times 39.52$

And from the separate Biographical Index:

DETAILle, JEAN BAPTISTE ÉDOUARD. Paris. Born in Paris, 1848. Favorite pupil of Meissonier. Exhibited at Salon, in 1868, his 'Halt of Infantry,' which received much praise, and in 1869 the 'Rest During Drill at Camp St. Maur,' which established his reputation as one of the most popular military painters of the day. Medals, Paris, $1860,{ }^{\prime} 70,{ }^{\prime} 72$. Legion of Honor, 1873; Officer of the same, 1881.

Nos. $48,134 .^{53}$

The catalogue entry gave minimal information, simply the artist's name, title of the artwork, Salon exhibition date, provenance-in this case from another American collection-the artwork's date and dimensions. The longer index entry listed awards as well as information regarding his early successful works. Because Meissonier was so highly regarded, the adjective 'favorite' before 'pupil' added prestige to an already impressive biography.

Wolfe's collection comprised mainly French works, but also a diverse number of other national schools. The table below shows that French art dominated her collection more so than it had the other three collections, but she owned works by artists of twelve different national schools, the same number as Vanderbilt.

At the Metropolitan Museum of Art, the Wolfe bequest occupied two adjacent galleries, called the Catharine Lorillard Wolfe Gallery. ${ }^{54}$ Wolfe's (and

52 Metropolitan Museum of Art. Part I. The Catharine Lorillard Wolfe Collection; Part II. Pictures by Old Masters, in the East Galleries (New York: Metropolitan Museum of Art, 1887), 10.

53 Metropolitan Museum of Art. Part I. The Catharine Lorillard Wolfe Collection, 19.

54 For more on Wolfe, see: Rebecca A. Rabinow, "Catharine Lorillard Wolfe: The First Woman Benefactor of the Metropolitan Museum of Art," Apollo 147, no. 433 (1998): 4855; Margaret Laster, "Catharine Lorillard Wolfe: Collecting and Patronage in the Gilded Age," (PhD diss., Graduate Center, City University of New York, 2013); Margaret Laster, "The Collecting and Patronage of Catharine Lorillard Wolfe in Gilded-Age New York and 


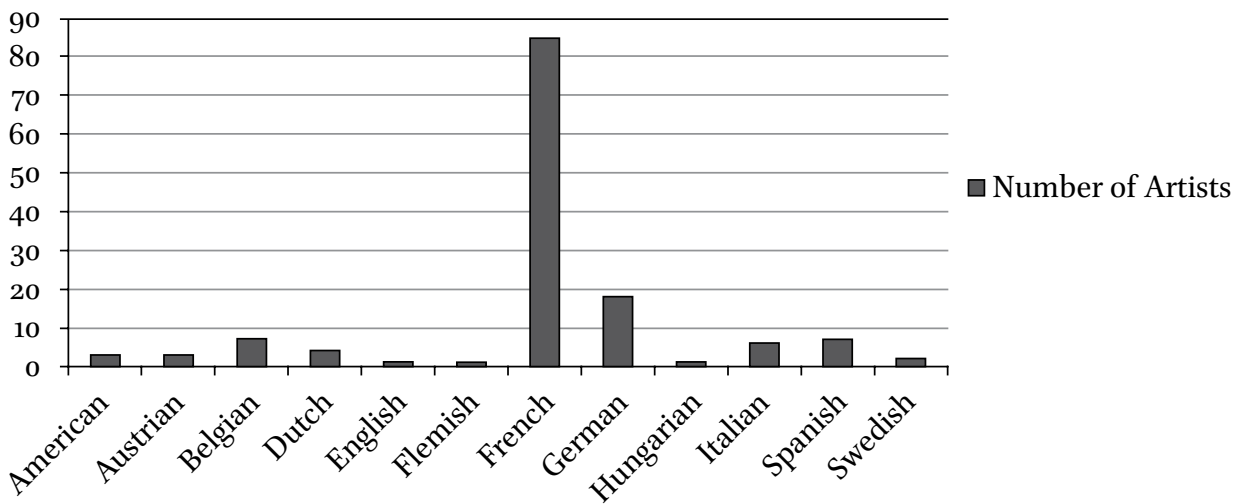

GRAPH 3 Nationalities Represented in the Catharine Lorillard Wolfe Collection, 1887

the other collectors') eclectic arrangement of pictures, hung without regard to groupings of national schools, persisted in the museum display (Fig. 3.3). In a larger sense, this perhaps reflected the heterogeneous society that characterised urban American demographics. New York was a city filled with immigrants, such as Belmont (b. Germany) and Stewart (b. Ireland), and descendants of immigrants, including Vanderbilt (Dutch) and Wolfe (German). Today, visitors typically find art by national schools displayed together in encyclopaedic museums, such as the Metropolitan Museum of Art and the Louvre. French art usually hangs amongst French art, Dutch amongst Dutch, etc. Contemporary displays seem more focused on national schools than they were in the nineteenth century, but modern art is treated as an international phenomenon, whereas nineteenth-century art is divided by schools. ${ }^{55}$ The Belmont, Stewart, Vanderbilt and Wolfe collection catalogues emphasised national schools in individual entries, yet the artists' works were interspersed among the catalogues and in the displays.

The William H. Vanderbilt Collection of Modern Pictures hung in another gallery next to the Wolfe collection at the Metropolitan Museum of Art from

Newport," in Power Underestimated: American Women Art Collectors, eds. Inge Reist and Rosella Mamoli Zorzi (Venice: Marsilio, 2011), 79-99; Dianne Sachko Macleod, Enchanted Lives, Enchanted Objects: American Women Collectors and the Making of Culture, 1800-1940 (Berkeley: University of California Press, 2008), 61-71; Leanne Zalewski, "The Golden Age of French Academic Painting in America, 1867-1893" (PhD diss., City University of New York, 2009), 174-81.

55 Andrew Hemingway, "American Art Pre-1940 and the Problem of Art History's Object," in Internationalizing the History of American Art, eds. Barbara Groseclose and Jochen Wieric (University Park: Pennsylvania State University Press, 2009), 66. 


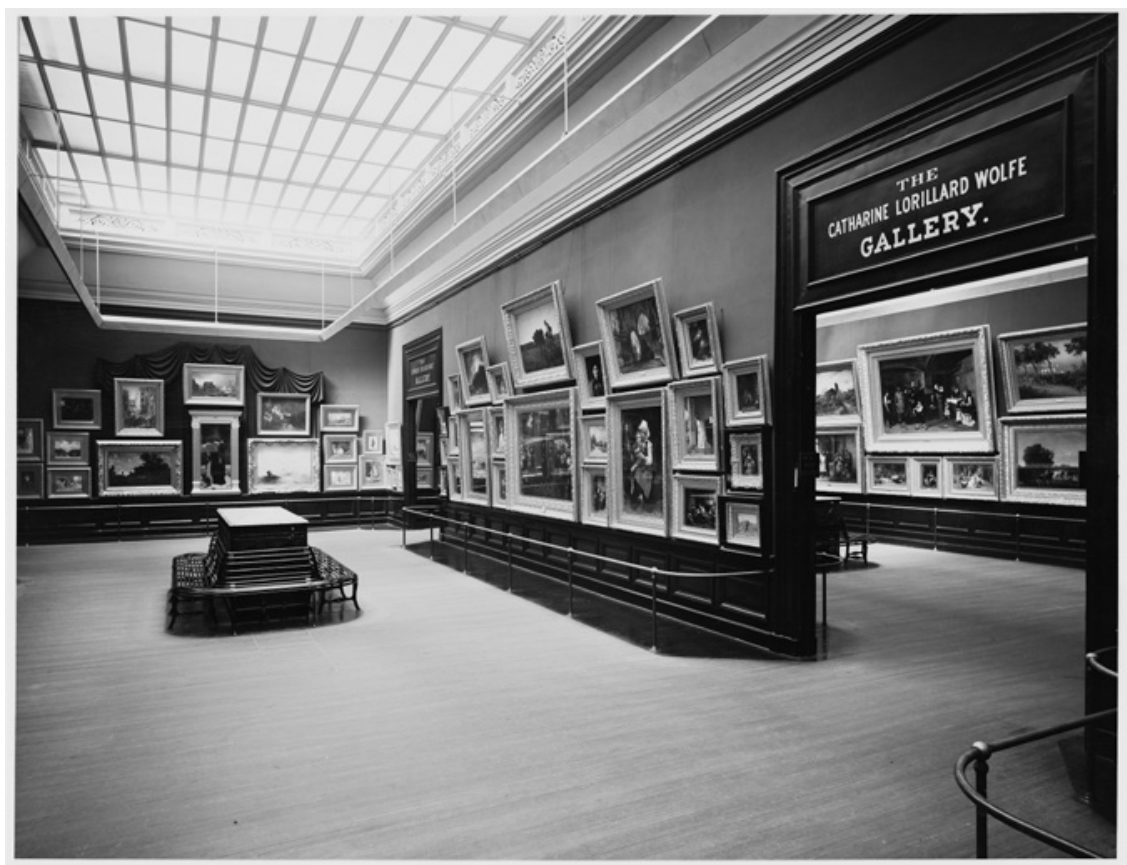

FIGURE 3.3 Anon., The Metropolitan Museum of Art, Paintings Gallery, Room 17:

The Catharine Lorillard Wolfe Gallery; View looking southwest, c. 1907. New York, The Metropolitan Museum of Art

(C) THE METROPOLITAN MUSEUM OF ART-ART RESOURCE, NEW YORK

1902 until early $1920 .{ }^{56}$ No photographs exist of the Vanderbilt Collection at the museum, but they likely hung as they had at his mansion, without regard to dividing them by national school. Vanderbilt arranged the pictures according to aesthetic concerns, size and symmetry, rather than by subject or school. French art hung alongside art from other European countries. His collection, like other collections in the United States, typically hung Salon style, or frameto-frame, just as the pictures were displayed in the Paris Salon, in French collectors' homes and in galleries. Catalogue numbers and entries, not grouped by national school, instead corresponded with the pictures' numbered arrangement in the galleries. ${ }^{57}$ For example, in Vanderbilt's gallery (Fig. 3.4), paintings by Constant Troyon, Jules-Joseph Lefebvre, Jean-Léon Gérôme, Jules Breton and Narcisse-Virgile Díaz de la Peña (all French) hung alongside works by Thomas Faed (Scottish), Lawrence Alma-Tadema (Dutch/English),

$5^{6}$ Samuel P. Avery, “W.H. Vanderbilt's Pictures on View," New York Times, 4 May 1902: 15.

57 Collection of W.H. Vanderbilt, 64 o Fifth Avenue, New York. 


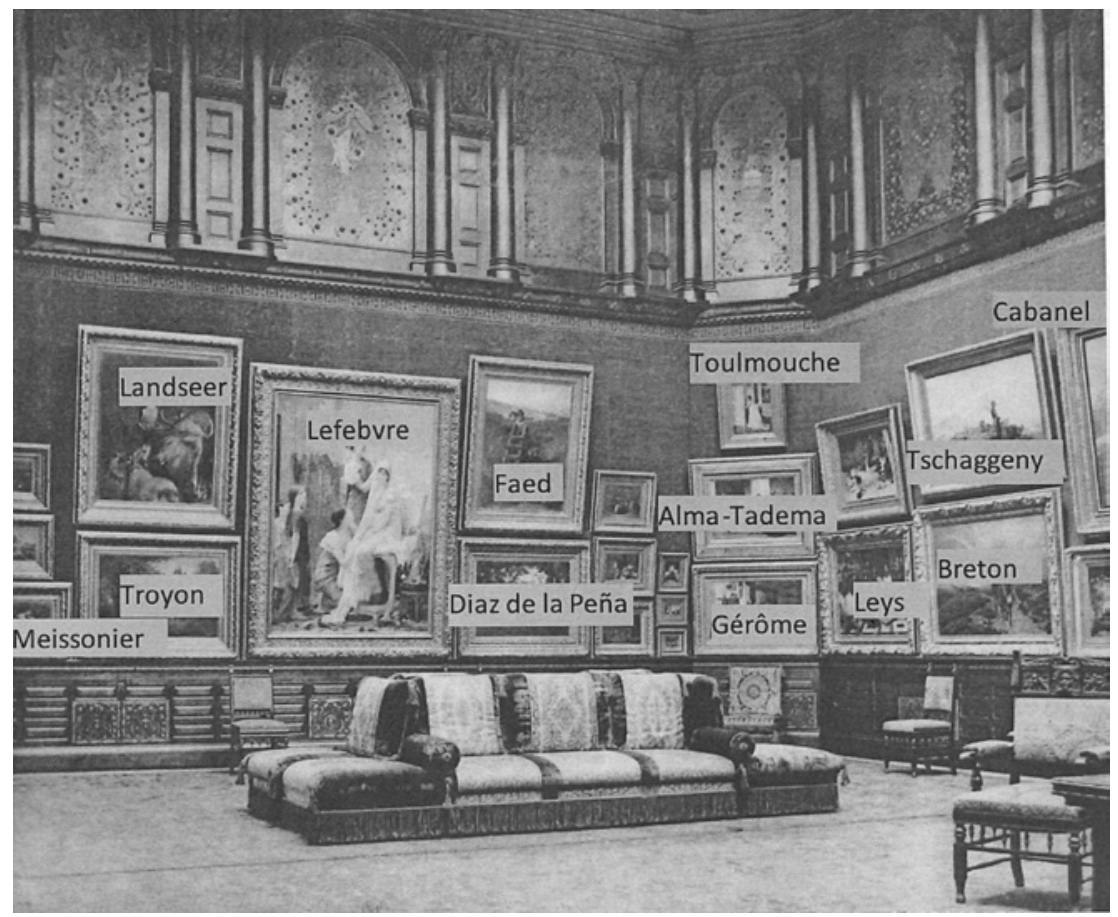

FIgure 3.4 Anon., View of William H. Vanderbilt's Private Art Gallery, c. 1883, in E. Strahan, Mr. Vanderbilt's House and Collection (Boston, 1883-84), s.p., labelled by Leanne Zalewski

(C) LEANNE ZALEWSKI

Edwin Landseer (English), Edmond Tschaggeny (Belgian) and Henri Leys (Belgian). Although not all of the works are easily identifiable, this sample demonstrates the diverse hanging and eclectic selection of European works. Catalogues aided in identifying the different national schools among the heterogeneous hanging.

\section{Conclusion}

Catalogues played an important role in communicating social and cultural capital. They helped educate auction and exhibition visitors, making them aware of the variety of schools and prestigious awards and honours system abroad. Belmont only published catalogues for special exhibitions and auctions, but not for the collection in his home. Neither Stewart nor Wolfe published collection catalogues to aid visitors. Only Vanderbilt printed several collection 
catalogues for visitors' edification. Catalogues printed in conjunction with exhibitions aided visitors in understanding the works, despite the lack of criticism contained on their pages. Rather than teach readers about the technical skill of the individual artworks, the catalogue entries emphasised institutional validation through connections to respected teachers, awards and exhibitions regardless of the catalogue's function. Such validation and provenance information confirmed the authenticity of the works. When letters were available, they were published in the catalogues to establish not only the subject matter depicted, but the relationship between the collector and artist.

The primary differences among the catalogues involves the inclusion of prefaces and separately published deluxe catalogues, which were illustrated. The two non-commercial Wolfe and Vanderbilt catalogues included prefaces written by art dealer Samuel P. Avery with information about the collectors. ${ }^{58}$ Avery's prefaces in both instances sought to validate the collectors' characters, in part by noting their extensive travels abroad, as well as endorse the collections' worthiness. Vanderbilt 'conferred with reliable experts,' primarily Avery, in his frequent travels across the Atlantic and in his art selections. ${ }^{59}$ Wolfe's biographical note emphasises her benevolence as well as her 'educated and refined taste. ${ }^{60}$ Undoubtedly as a means to overcome her perceived handicap as a single woman collector, unusual for her time, Avery presented her as following in her charitable father's footsteps. In addition he credited her with independent thought regarding her art collecting, but only after stating that she relied on her male cousin. These references legitimised this woman's collection as worthy of the museum's permanent collection.

Deluxe oversize illustrated catalogues of Stewart's and Vanderbilt's collections were published in addition to the standard versions. During his lifetime Vanderbilt had his mansion and art collection documented and published in beautifully illustrated volumes with both black-and-white and colour images. ${ }^{61}$ Awareness of the collection's significance as a model for other collectors helped motivate the publication. Stewart's sale catalogue was also published in a deluxe, illustrated edition. ${ }^{62}$ Stewart, however, was not involved. As John Ott noted, auctioneers Kirby \& Sutton produced three catalogues for Stewart's sale, one a "thick guidebook," as a lavishly illustrated catalogue for a

\footnotetext{
$5^{8}$ Catalogue of the Paintings in the Metropolitan Museum of Art, 127-8.

$59 \quad I d ., 128$.

6 Id., $179-83$.

61 Edward Strahan [Earl Shinn], Mr. Vanderbilt's House and Collection, 4 vols. (Boston: G. Barrie, 1883-84).

62 Catalogue of the A.T. Stewart Collection of Paintings, Sculptures, and Other Objects of Art (New York: J. J. Little \& Co., 1887).
} 
blockbuster sale. ${ }^{63}$ Offering a deluxe alternative sale catalogue along with the simpler version provided a souvenir of the sale as well as indicated the collection's importance. Such expensive catalogues were sold by subscription to the wealthy. Unfortunately for posterity, the Belmont and Wolfe collections were not published in separate, illustrated editions.

Although Belmont, Stewart, Vanderbilt and Wolfe lived in New York, their collections are representative of a broader pattern of collecting across the United States at that time. Regardless of the type of exhibition, collections featured a variety of national schools that enhanced the cultural value of the collections and the cultural knowledge of the collectors. National schools were intermingled in the catalogues as well as in the display. The artists' names, their teachers' names, nationalities, awards and honours, provenances, and additional descriptions or letters to collectors lent cultural and commercial value, provided an artistic lineage and by extension, authenticity, which attested to the internationalisation of the market and alluded to the collectors' knowledge and status. These collections' international emphasis provided cultural capital for the young nation. This process is evident even in something as seemingly insignificant as a catalogue. Further study of the works and catalogues for these and other collections would surely yield a more complex story of art collecting in the United States.

\section{References}

Anon. "Development of Nationality in American Art." Bulletin of the American ArtUnion, no. 9 (1851): 137-39.

Anon. [Samuel P. Avery]. "Catharine Lorillard Wolfe Collection and Other Modern Paintings in the Western Galleries, Stairways, and Grand Hall." In Metropolitan Museum of Art Handbook No. 1. New York: Metropolitan Museum of Art, 1894.

Avery, Samuel P. “W.H. Vanderbilt's Pictures on View." New York Times, 4 May 1902: 15. Avery, Samuel P. The Diaries 1871-1882 of Samuel P. Avery. Edited by Madeleine FidellBeaufort, Herbert L. Kleinfield, and Jeanne K. Welcher. New York: Arno Press, 1979. Ayres, William S. "The Domestic Museum in Manhattan: Major Private Art Installations in New York City, 1870-1920." PhD diss., University of Delaware, 1993.

Bayer, Thomas M., and John R. Page. The Development of the Art Market in England: Money as Muse, 1730-190o. London: Pickering \& Chatto, 2011.

63 Ott, "How New York Stole the Art Market," 137. 
Beckert, Sven. "Institution-Building and Class Formation: How the Nineteenth-Century Bourgeoisie Organized." In The American Bourgeoisie: Distinction and Identity in the Nineteenth Century, edited by Sven Beckert and Julia Rosenbaum, 103-17. New York: Palgrave Macmillan, 2011.

Boime, Albert. "America's Purchasing Power and the Evolution of European Art in the Late Nineteenth Century." In Saloni, gallerie, musei e loro influenza sullo sviluppo dell'arte dei secoli xix e xx, edited by Francis Haskell, 123-39. Bologna: CLUEB, 1979.

Bourdieu, Pierre. "The Forms of Capital (1986)." In Education: Culture, Economy and Society, edited by A.H. Halsey et al., 46-58. Oxford: Oxford University Press, 1997.

Bryan, Thomas Jefferson. Companion to the Bryan Gallery of Christian Art. New York: Baker, Godwin \& Co., 1853 .

Cantor, Jay E. "A Monument of Trade: A.T. Stewart and the Rise of the Millionaire's Mansion in New York." Winterthur Portfolio 10 (1975): 165-97.

Catalogue of a Private Collection of Original Modern Oil Paintings and Water Color Drawings Belonging to J. Wolfe [...] To Be Sold by Auction [...] December, 1863. New York: Henry H. Leeds \& Co., 1863.

Catalogue of a Remarkably Fine Collection of Oil Paintings by the Best American Artists, Also, A Number of Choice Foreign Works [...] Consigned to Mr. S.P. Avery. New York: Henry H. Leeds \& Miner, 1866.

Catalogue of the A.T. Stewart Collection of Paintings, Sculptures, and Other Objects of Art. New York: J.J. Little \& Co., 1887.

Catalogue of the Paintings in the Metropolitan Museum of Art. New York: Metropolitan Museum of Art, 1902.

Catalogue of the W.H. Vanderbilt Collection of Paintings. New York: De Vinne Press, 1886.

Cohen Tervaert, Renske. "L'art pour l'argent." MA thesis, University of Amsterdam, 2008.

Collection of W.H. Vanderbilt, 640 Fifth Avenue, New York. New York: Putnam, 1882.

Collection of W.H. Vanderbilt, 64 o Fifth Avenue, New York. New York: s.n., 1884.

Conway, M.D. “The Great Show at Paris." Harper's New Monthly 35, no. 206 (1867): 238-53.

DeCourcey, McIntosh E., Gabriel P. Weisberg, and Alison McQueen, eds. Collecting in the Gilded Age: Art Patronage in Pittsburgh, 1890-1910. Pittsburgh: Frick Art \& Historical Center, Hanover - London: University Press of New England, 1997.

Durand-Gréville, Émile. "French Pictures in America." Studio 2, no. 2 (1887): 29-33.

Durand-Gréville, Émile. "La peinture aux États-Unis: les galeries privées." Gazette des beaux-arts 36 (1887): 65-75.

Durand-Gréville, Émile. “Private Picture-Galleries of the United States." The Connoisseur 2, no. 3 (1888): 137-42. 
Explication des ouvrages de peinture, sculpture, architecture, gravure et lithographie des artistes vivants, exposés au Palais des Champs-Élysées le 1er mai 1876. Paris: Imprimerie nationale, 1876 .

Fidell-Beaufort, Madeleine. "A Measure of Taste: Samuel P. Avery's Art Auctions, 18641880." Gazette des beaux-arts 100 (1982): 87-9.

Fidell-Beaufort, Madeleine. "The American Art Trade and French Painting at the End of the Nineteenth Century." Van Gogh Museum Journal 6 (2000): 101-7.

Fidell-Beaufort, Madeleine. "Art Collecting in the United States after the Civil War: Civic Pride, Competition, and Personal Gains." In Artwork through the Market: The Past and the Present, edited by Ján Bakos, 125-36. Bratislava: VE DA, 2004.

Fidell-Beaufort, Madeleine, and Jeanne K. Welcher. "Some Views of Art Buying in New York in the 1870s and 188os." Oxford Art Journal 5, no. 1 (September 1982): 48-55.

Fletcher, Pamela, and Anne Helmreich, eds. The Rise of the Modern Art Market in London: 1850-1939. Manchester - New York: Manchester University Press, 2011.

Gérôme \& Goupil: Art and Enterprise. Paris: Réunion des musées nationaux, 2001.

Goldstein, Malcolm. Landscape with Figures: A History of Art Dealing in the United States. New York: Oxford University Press, 2000.

Green, Nicholas. "Dealing in Temperaments: Economic Transformation of the Artistic Field in France during the Second Half of the Nineteenth Century." In Critical Readings in Impressionism and Post-Impressionism: An Anthology, edited by Mary Tompkins Lewis, 31-47. Berkeley: University of California Press, 2007.

Greenblatt, Stephen et al. Cultural Mobility: A Manifesto. Cambridge: Cambridge University Press, 2010.

Hemingway, Andrew. "American Art Pre-1940 and the Problem of Art History's Object." In Internationalizing the History of American Art, edited by Barbara Groseclose and Jochen Wieric, 61-79. University Park: Pennsylvania State University Press, 2009.

Henefield Skalet, Linda. "The Market for American Painting in New York: 1870-1915." PhD diss., Johns Hopkins University, 1980.

Isaacson, Robert. "Collecting Bouguereau in England and America." In William Bouguereau, 1825-1905, 104-13. Montreal: Montreal Museum of Art, 1984.

Kramer, Lloyd. Nationalism in Europe \& America: Politics, Cultures, and Identities since 1775. Chapel Hill: University of North Carolina Press, 2011.

Laster, Margaret. "The Collecting and Patronage of Catharine Lorillard Wolfe in Gilded-Age New York and Newport." In Power Underestimated: American Women Art Collectors, edited by Inge Reist and Rosella Mamoli Zorzi, 79-99. Venice: Marsilio, 2011.

Laster, Margaret. "Catharine Lorillard Wolfe: Collecting and Patronage in the Gilded Age." PhD diss., Graduate Center, City University of New York, 2013. 
Lucas, George A. Diary of George A. Lucas: An American Art Agent in Paris, 18571909. Edited by Lilian M.C. Randall. 2 vols. Princeton: Princeton University Press, 1979.

McNair Bolin, Anne. "Art and Domestic Culture: The Residential Art Gallery in New York City, 1850-1870." PhD diss., Emory University, 2000.

Meixner, Laura L. French Realist Painting and the Critique of American Society, 186519oo. New York: Cambridge University Press, 1995.

Metropolitian Museum of Art. Part I. The Catharine Lorillard Wolfe Collection. New York: Metropolitan Museum of Art, 1887.

Metropolitan Museum of Art. Part II. Pictures by Old Masters, in the East Galleries. New York: Metropolitan Museum of Art, 1887.

Notice des peintures, sculptures et dessins de l'école moderne exposés dans les galeries du Musée national du Luxembourg. Paris: Charles de Mourgues frères, 1875.

Orcutt, Kimberly. Power and Posterity: American Art at Philadelphia's 1876 Centennial Exhibition. University Park: Penn State University Press, 2017.

Ott, John. "How New York Stole the Art Market: Blockbuster Auctions and Bourgeois Identity in Gilded Age America." Winterthur Portfolio 42, no. 2-3 (2008): 133-58.

Ott, John. Manufacturing the Modern Patron in Victorian California. Burlington: Ashgate, 2014.

Penot, Agnès. La maison Goupil. Galerie d'art internationale au XIX $X^{e}$ siècle. Paris: Mare \& Martin, 2016.

Public Exhibition of the Belmont Collection for the Benefit of the Family of the Late Artist, Mr. J. Beaufain Irving. New York, 1877.

Rabinow, Rebecca A. "Catharine Lorillard Wolfe: The First Woman Benefactor of the Metropolitan Museum of Art." Apollo 147, no. 433 (1998): 48-55.

Résumé du catalogue des tableaux anciens et modernes des diverses écoles, dont la vente aura lieu [...] les 6, 7, 8, et 9 mars 1872 [...]: galerie de MM. Péreire. Paris: François Petit, 1872 .

Sachko Macleod, Dianne. Enchanted Lives, Enchanted Objects: American Women Collectors and the Making of Culture, 1800-1940. Berkeley: University of California Press, 2008.

Strahan, Edward [Earl Shinn]. Art Treasures of America. 3 vols. Philadelphia: George Barrie, $1879-82$.

Strahan, Edward [Earl Shinn]. Mr. Vanderbilt's House and Collection. 4 vols. Boston: G. Barrie, $1883^{-84}$.

The Private Collection of W.H. Vanderbilt, 459 Fifth Avenue, New York. New York: G.P. Putnam's Sons, 1879 .

Troyen, Carol. "Innocents Abroad: American Painters at the ${ }_{1867}$ Exposition Universelle, Paris." American Art Journal 16, no. 4 (1984): 2-29. 
White, Harrison C., and Cynthia A. White. Canvases and Careers: Institutional Change in the French Painting World. Chicago: University of Chicago Press, 1993.

Zafran, Eric M. "William Bouguereau in America: A Roller-Coaster Reputation." In In the Studios of Paris: William Bouguereau and his American Students, edited by James F. Peck, 17-44. Tulsa: Philbrook Museum of Art, New Haven: Yale University Press, 2006.

Zalewski, Leanne. "The Golden Age of French Academic Painting in America, 18671893." PhD diss., City University of New York, 2009.

Zalewski, Leanne. "Art for the Public: William Henry Vanderbilt's Cultural Legacy." Nineteenth-Century ArtWorldwide11, no.2 (Summer 2012), http://www.19thc-artworld wide.org/summern2/leanne-zalewski-william-henry-vanderbilts-cultural-legacy. 